International Journal of Linguistics, Literature and Culture
Available online at https://sloap.org/journals/index.php/ijllc/
Vol. 6, No. 6, November 2020, pages: 1-7
$\begin{aligned} & \text { ISSN: 2455-8028 } \\ & \text { https://doi.org/10.21744/ijllc.v6n6.961 }\end{aligned}$

\title{
Duality in Two West African Literary Genres: Achebe's A Man of the People and Soyinka's The Lion and the Jewel
}

Bazimaziki Gabriel ${ }^{a}$

Article history:

Submitted: 27 July 2020

Revised: 18 August 2020

Accepted: 09 September 2020

Keywords:

duality;

modernity;

symbol;

themes;

tradition;

\begin{abstract}
Literature is a dual discipline as it deals with human beings and their environment at monist and dualist levels. Duality in literature in this respect arouses considerable interest here. It is explored in West African writings with a particular focus on Achebe's A Man of the People and Soyinka's The Lion and the Jewel. Both authors' use of duality for each is examined by attempting to measure the two literary works' main characters and the leading themes. Achebe's Chief Nanga and his antagonist, Odili, are compared to Soyinka's Baroka and his rival Lakunle. Sidi the center of the conflict in Soyinka's play is measured to Achebe's Edna. Both writers' works are examined under the plane of the conflict of generations. The two literary works exhibit the themes of tradition versus modernity depicted through their characters. The analysis revealed that a character in one genre may be different from or similar to another's story character from a similar or different setting.
\end{abstract}

International journal of linguistics, literature and culture () 2020. This is an open access article under the CC BY-NC-ND license (https://creativecommons.org/licenses/by-nc-nd/4.0/).

\section{Corresponding author:}

Bazimaziki, G.

University of Rwanda - College of Education, Department of Humanities and Language Education P.O BOX 55

Rwamagana, Rwanda

Email address: bazimazikigabriel@yahoo.com

\footnotetext{
${ }^{a}$ University of Rwanda - College of Education, Department of Humanities and Language Education, Rwamagana, Rwanda
} 


\section{Introduction}

Generally, literature is a dual discipline dealing with how people act one another depending on the situation in which they are, and how human good or bad manners to others are more often than not influenced by nature. Human nature is dictated by the environment; that is, factors such as time and space, people acting for or against others, among other things, determine how one has to cope with life hurdles. Good and evil, qualities, and flaws are oftentimes the widely depicted themes in various kinds of literature in many parts of the globe. West African Literature is no exception. Literary forms and genres found there depict not only the ways of traditional society but also reflect the current African values and human manners in their spatial and physical settings. Prose fiction and drama set in Nigeria are good examples of forms and genres which depict human society through a variety of themes including but not limited to African culture, conflict of generations, tradition versus modernity, corruption and injustice, irresponsibility and don't care attitude. In West African Literature, Achebe and Soyinka are two pioneer writers whose interests are mainly concerned with African culture depicted throughout their characters in various genres. A character in one genre may differ from or be similar to another's story character but from different settings. According to Moawad (2016), Soyinka's characters challenge themselves in an atmosphere punctuated with the defenders of modernity in one camp and those who are deeply rooted in the traditions and customs on the other side. Similarly, Achebe's fiction addresses the issue of the traditional way of life in conflict with the new one. He exemplifies his goal of social realism and his attempts to restore the lost dignity of his people (Dwivedi, 2008; Fohrmann, 1988; Lizardo, 2018; Kostalevsky, 1998). Thus, this study examines duality in the two authors' works emphasizing characters and themes; two interwoven literary elements that are often time hard, if not impossible, to disconnect altogether.

This study aimed to carry out literary analysis. Not all literary generic elements were explored. Rather, particular interest was directed in how duality is used in two literary works in African Literature in general, Nigerian Literature in particular. One is A Man of the People and another, one of Achebe's fictitious prose narratives. Another is The Lion and the Jewel, one of the plays by Soyinka, the famous Nigerian playwright, and pioneer novelist. The researcher wanted to look at some characters taking account of themes affecting each of them. The reason to discuss the two concurrently is that each of the two cannot be studied without talking about another. They are like time and space which, in the view of Guy (2001), cannot be practically defined independently because measurement operations of space take time. Further, the researcher wanted to throw light on the message that is conveyed through the two West African literary works. The study sought to answer the following questions: (1) what is duality and how is it used in literature? (2) How are some characters in A Man of the People comparable to those in The Lion and the Jewel? (3) To what extent are the two stories relevant to the African communities?

\section{Theories and Methods}

Literature and Philosophy are two subjects that cannot be distanced completely. Both deal with man and nature, human beings, and the world in which they live. Literature involves human life while Philosophy is primarily concerned with human wisdom. Both are sciences in the sense that they base on hypotheses testing and critical thinking, leading to concluding. Literature depicts human society at large while Philosophy goes beyond human society with a particular interest in "Why" of everything as it is concerned with general problems related to reality, existence, knowledge, values among other things. In both subjects, the term "duality" has won a good ground and needs to be discussed in this study. In Philosophy, the term duality is related to dualism which posits that, for some particular domains, there are two fundamental kinds or categories of things or principles. In Literature, the term "duality" cannot be expelled as it is used in some literary works, authors having the intent to convey their thoughts. Studies reveal that duality can literarily be expressed mainly based on two generic elements such as characters and plot. In other words, people, their actions, imaginations, and situations they experience in a cause-effect relationship, are means through which book authors reveal duality, by showing how a story takes place, the types of characters, and their actions for each.

Characterization and plot hold a big part in this study because characters cannot be discussed regardless of what they are doing and how they are doing it in a story. Moreover, this study hinges on dualism theory. Research reveals that the binary oppositions of various dualisms - good and bad, light and darkness, eschatological bliss and contemporary suffering, transcendence and immanence, mind and body, heaven and earth - have had broad appeal throughout human history and they persist into the modern world, even shaping contemporary political and ethical 
debates (Lange et al., 2011; Middleton et al., 2001; Hernadi, 1981). Added to this, human nature is characterized by two sides which he should control when making decisions. If he succeeds to control himself, he takes the right decision and contrarily, he makes a wrong decision which often leads to failure. How he behaves is what determines who he is and how he can be coping with life in the world. Begley (2012) considers the term 'duality' to stand for opposition or dichotomy between, or of, two entities. He uses examples such as day and night, left and right, positive and negative, life and death, male and female, up and down, true and false, right and wrong, etc. The same author concludes that the term 'duality', and certain synonyms of it, is already in use in the contexts of various scientific and philosophical fields of research [without expelling literary field]. In a similar view, McDonald (2008) believes that the term duality is referred to as "two conceptually distinctive ideas that are interrelated" or "two conceptually distinctive ideas that share no middle ground..." Elsewhere, the term duality designates the tendency to classify phenomena into opposing groups. Duality is related to dualism which, in the view of Robinson (2017) contrasts with monism, a theory that there is only one fundamental kind, category of thing or principle.

Thus, this essay is a literary analysis that hinges on a comparison of characterization and themes in two West African stories. Hence Comparative approach cannot be left out in this literary essay. Discussion and interpretation are framed on duality theory referred hereto as a situation of two distinctive things in nature as the novel is to play, fiction to non-fiction, tradition to modernity, good to evil, one to the other, space to time, light to darkness, right to wrong, justice to injustice, love to hate, young to old, progressive to static, etc. The study is by and large a descriptive literary analysis that dealt with qualitative data as streaming from The Lion and the Jewel and A Man of the People.

\section{Results and Discussions}

This discussion is geared by a dualist approach that reflects a distinction between an individual and another. In $A$ Man of the People, Odili Samaru and Chief Nanga are concerned with this situation. One can describe them based on their deeds, their wishes, and their behaviors in the story. Achebe depicts Postcolonial Africa through the two characters. According to Dwivedi (2008), Achebe portrays how the world appears through A Man of the People, one of the realistic novels. The novel depicts the ills of bad politics of injustice and corruption done on the victim citizens; and the will to fight these malpractices. Chief Nanga and Odili are two antagonists in this story. They are two characters of different behaviors among their people. Chief Nanga is a - too - much - proud political manipulator and a corrupt leader whose interests lie in increasing his wealth and power by the means of the position of Minister of Culture he holds. While he is responsible to preserve the culture of the country, he does not. He is ironically described as a man of the people in that 'No one can deny that Chief the Honourable M.A. Nanga, M.P., was the most approachable politician in the country. Whether you asked in the city or his home village, Anata, they would tell you he was a man of the people.'(Achebe, 1966) This is a satirical style revealing the extent to which Chief Nanga's bad leadership was critically reflected by his deeds. Indeed, Odili accuses him of injustices, corruption, and related defectives which downfalls the country as well explained below:

As I stood in one corner of that vast tumult waiting for the arrival of the Minister I felt intense bitterness welling up in my mouth. Here were silly, ignorant villagers dancing themselves lame and waiting to blow off their gunpowder in honour of one of those who had started the country off down the slopes of inflation. I wished for a miracle, for a voice of thunder, to hush this ridiculous festival and tell the poor contemptible people one or two truths. But of course it would be quite useless. They were not only ignorant but cynical. Tell them that this man had used his position to enrich himself and they would ask you---as my father did---if you thought that a sensible man would spit out the juicy morsel that good fortune placed in his mouth (Achebe, 1966).

The above words reflect Odili's speaking voice for people whose human rights are violated. Despite his low position as a school teacher, he is now convinced to lead the opposition against Nanga's power. Odili is a symbol of the changing younger generation while Nanga represents traditional African manners. He is a socialist activist who attempts to denounce and expose Nanga's inadequacy (Morrison, 2007). Their antagonism and rivalry over Edna, a young beautiful girl, is another issue. Achebe (1966) put it as follows:

Bazimaziki, G. (2020). Duality in two west african literary genres: achebe's a man of the people and soyinka's the lion and the jewel. International Journal of Linguistics, Literature and Culture, 6(6), 1-7. https://doi.org/10.21744/ijllc.v6n6.961 
I knew then that I wanted Edna now (if not all along) for her own sake first and foremost and only very remotely as part of a general scheme of revenge. I had started off telling myself that I was going for her in order to hurt Chief Nanga; now I would gladly chop off Chief Nanga's head so as to get her. Funny, wasn't it? Having got that far in my self-analysis I had to ask myself one question. How important was my political activity in its own right? It was difficult to say; things seemed so mixed up; my revenge, my new political ambition and the girl. And perhaps it was just as well that my motives should entangle and reinforce one another. I was not being so naïve as to imagine that loving Edna was enough to wrench her from a minister. True, I had other advantages like youth and education but those were nothing beside wealth and position and the authority of a greedy father. No. I needed all the reinforcement I could get. Although I had little hope of winning Chief Nanga's seat, it was necessary nonetheless to fight and expose him as much as possible so that, even if he won, the Prime Minister would find it impossible to re-appoint him to his Cabinet (Achebe, 1966).

Odili 's words reflect a two-fold antagonism with Nanga. First, Odili is politically trying to compete and win over Nanga whom he accuses of inadequacy, injustice, and greed as well. Second, the trio-love affair is another fight Odili vowed to win despite his opponent's position and material power. Chief Nanga is well aware that his antagonist leaves no stone unturned to fight him at two levels as he is telling the public all that is happening at his expense. He openly reveals that he vainly provided Odili with the bread-and-butter. He accuses him of ungratefulness and betrayal as he says:

My people' said Nanga again. 'This is the boy who is thrusting his finger into my eye. He came to my house in Bori, ate my food, drank my water and my wine and instead of saying thank you to me he set about plotting how to drive me out and take over my house.' [...] 'He even tried to take a girl on whose head I had put the full bride-price and many other expenses---and who according to our custom is my wife--this girl here....' He went over to Edna and roughly pulled her hands away from her face. 'He tried to take this girl who is covering her face for shame. Fortunately my wife caught him and told me.' He turned aside from the crowd to me. 'Odili the great! So you have come to seek me out again. You are very brave; or have you come to seek Edna, eh? That's it (Achebe, 1966).

In the above passage, Chief Nanga is ironically and mockingly showing Odili that he is not powerful enough to win him. When asked about what brought him there, Odili categorically and ostensibly tells that 'He came to tell Nanga's people that he [Nanga] is a liar and...'[...]. Such words made Nanga be vexed and slap Odili's face again and again. Nanga's political power is now and gradually becoming more and more volatile until he is arrested in the end while Odili is exonerated from all the blame. It is the end whereupon the hunted takes privilege at the expense of the hunter.

Elsewhere, although the story of the play The Lion and the Jewel presents a trio- the relationship among three characters namely Sidi, a village beauty, Lakunle, a young local teacher infatuated with her beauty along with western ways of life, and Baroka, the village head( Mansur, 2016), they behave and act differently hence they are shaped dually. Baroka, the village chief, is a symbol of traditional values. He is wise and cunning in his rivalry against Lakunle. Baroka is more experienced than his opponent. Although he is a middle-aged man, he represents the old generation but believes both young and old need one another and that modernity has some positive side as he says:

For a long time now,

The town - dwellers have made up tales

Of the backwardness of Ilujinle

Until it hurts Baroka, who holds

The welfare of his people deep at heart $[\ldots]$

I do not hate progress, only its nature 
Which makes all roofs and faces look the same.

[...]

It is a bad thing, then, to sound

Like your school teacher?

Your school teacher and I are much alike.

The proof of wisdom is the wish to learn

Even from children. And the haste of youth

Must learn its temper from the gloss

Of ancient leather, from a strength

Knit close along the grain. The schoolteacher

And I, must learn one from another (Soyinka, 1963)

From the above words, Baroka mentions that both young and old generation need mutually. He thinks the school teacher [Lakunle] and he need each other although they are wooing one beauty. As a young school teacher, Lakunle is a symbol of the eye and hope of the new generation aiming at social change. We are shown that Lakunle is too arrogant and overproud as he compares Sidi as stubborn as an illiterate goat (Soyinka, 1974). He is bound with modernity and progress, unlike Baroka who is static. Mansur (2016) describes the two in a way that Lakunle woos Sidi and is willing to marry her, but he is not willing to pay the bride price as is common for marrying a chaste girl. On the other hand, the author goes on, Baroka, is described as a wife hunting old man trying to have Sidi as his wife. Baroka wishes he married Sidi so that, as a virgin, the youngest and freshest of wives, she would save his pride (Soyinka, 1974). In this context, the center of the core conflict is Sidi, the belle of the village. This is another character whose role in the story calls the reader's attention. She is a dual character whose choice between tradition and modernity is a difficult equation to solve. In the view of Moawad (2016) and Basim \& Lajiman bin (2019), Sidi sees value in both men and it is hard to choose one of them over another. The author concludes that such a situation reflects the conflict between modern and tradition; whereby most Nigerians of that time are puzzled and caught between two worlds and wonder which one they would prefer to live in.

Besides the use of duality, while shaping their characters, both authors used duality to convey the themes affecting characters in each of the two stories. In many African writings, progression contrasts with tradition, the latter being accused of backwardness and darkness. It follows that in many cases modernity generally primes over tradition. However, the situation in The Lion and the Jewel contrasts such belief. The rivalry between Baroka and Lakunleshows that, I in fact that, in the view of Nagendra (2013), Soyinka portrays Baroka and Lakunle by juxtaposing them. Baroka is presented in a much more favorable light than Lakunle. The author opines that the triumph of Baroka over Lakunle leads readers and critics to view this victory of old Africa over foreign-educated upstarts. Hence, the idea of tradition versus modernity cannot be excluded from important themes to be discussed in this essay.

Basim Khudhair \& Lajiman bin (2019) analyze Wole Soyinka's play, The Lion and the Jewel from the angle of clash of cultures to urge and contend that the play displays the theme of culture conflict [modern and old cult cultures], ribald comedy, and love. They opine that the old culture represented by the uneducated people in Ilunjunle, led by Baroka, Sidi, and the rest, clashes with the new culture led by Lakunle, who is educated, a school teacher by profession influenced by the western ways. The young versus old generation cannot be left out. Odili and Lakunle are symbols of young generations whose views diverge with old perceptions such as depicted in the image of Nanga and Baroka. It is a similar situation to the antagonism between Nanga his former student Odili. For each side, characters have two different types of personality and do not project in the same direction.

Thus far, both authors used duality in shaping their characters each in his literary work. We have seen that Chief Nanga and Odili conflict over Edna besides political issues related with the corruption and injustice practiced against people; while Baroka - a polygynous village chief, conflicts with Lakunle - a young school teacher, over Sidi considered as the beauty of Ilujinle, a Yoruba village in West African region. The play is depicted as a clash of cultures.

Bazimaziki, G. (2020). Duality in two west african literary genres: achebe's a man of the people and soyinka's the lion and the jewel. International Journal of Linguistics, Literature and Culture, 6(6), 1-7. https://doi.org/10.21744/ijllc.v6n6.961 


\section{Conclusion}

This study is anchored on duality in West African writings. Achebe's A Man of the People and Soyinka's The Lion and the Jewel were used as primary sources. The two literary works were explored with particular emphasis on the main characters on the one hand and the leading themes on the other side. It was found out that both works exhibit dual characters and themes affecting them in each. Achebe's Chief Nanga and his antagonist Odili were compared to Soyinka's Baroka and his opponent Lakunle. Sidi as the center of the conflict in The Lion and the Jewel was measured to Achebe's Edna. Thus, the two literary works depict the two opposing themes of tradition and modernity in Africa, in the Nigerian setting in particular.

\section{Conflict of interest statement}

The author declared that he has no competing interests.

\section{Statement of authorship}

The author has a responsibility for the conception and design of the study. The author has approved the final article.

\section{Acknowledgments}

I am grateful to two anonymous reviewers for their valuable comments on the earlier version of this paper. 


\section{References}

Achebe, C. (1966). A Man of the People. UK: Heinemann.

Basim K. S. \& Lajiman bin, J. (2019).Cultural clash in Wole Soyinka's play: The Lion and the Jewel. International Journal of English Research, 5(1), 71-77.

Begley, K. (2012). The Concept of Duality and its Representation in Language as Antonymy .Paper presented at the joint TCD/UCD graduate work-in-progress seminar on the 3rd of April 2012, in Trinity College Dublin Retrieved from https://www.academia.edu/2766205/

Dwivedi, S. K. (2008). Parul Rastogi Babasaheb Bhimrao Ambedkar University "An Entropy Based Method For Removing Web Query Ambiguity In Hindi Language”. Journal Of Computer Science, 4(9), 762-767.

Dwivedi, V. (2008). Aspects of realism in Chinua Achebe's A Man of the People.

Fohrmann, J. (1988). Remarks towards a theory of literary genres. Poetics, 17(3), 273-285. https://doi.org/10.1016/0304-422X(88)90035-6

Guy, B. (2002). The duality of space and time and the theory of relativity. Journal of New Energy, 6, 46-71.

Hernadi, P. (1981). Entertaining commitments: a reception theory of literary genres. Poetics, 10(2-3), 195-211. https://doi.org/10.1016/0304-422X(81)90034-6

Kostalevsky, M. (1998). The Young Godunov-Cherdyntsev or How to Write a Literary Biography. Russian Literature, 43(3), 283-295. https://doi.org/10.1016/S0304-3479(98)80004-5

Lange, A., Meyers, E. M., Reynolds III, B. H., \& Styers, R. (2020). Light against darkness: dualism in ancient Mediterranean religion and the contemporary world. Journal of Ancient Judaism Supplements, 2.

Lizardo, O. (2018). The mutual specification of genres and audiences: Reflective two-mode centralities in person-toculture data. Poetics, 68, 52-71. https://doi.org/10.1016/j.poetic.2018.04.003

McDonald, L. (2008). Duality in Dr. Jekyll and Mr. Hyde, The picture of Dorian Gray, and" Dionea".

Middleton, T. F., Ferket, P. R., Boyd, L. C., Daniels, H. V., \& Gallagher, M. L. (2001). An evaluation of co-extruded poultry silage and culled jewel sweet potatoes as a feed ingredient for hybrid tilapia (Oreochromis niloticus $\times$ O. mossambicus). Aquaculture, 198(3-4), 269-280. https://doi.org/10.1016/S0044-8486(00)00601-3

Moawad, N. M. I. (2016). A Study of Wole Soyinkas play The Lion and the Jewel in the light of cultures in conflict. International Journal of English and Literature, 7(12), 179-188.

Monsur, A. (2016). Wole Soyinka's Style of Presentation in The Lion and the Jewel. Journal of Humanities, Social Sciences and Business Studies, 2(2), 83-90.

Morrison, J. (2007). Chinua Achebe's A Man of the People: the Novel and the Public Sphere. In Scandalous Fictions (pp. 117-135). Palgrave Macmillan, London.

Nagendra, S. (2013) Critical Analysis of the Play The Lion and The Jewel by Wole Soyinka. International Journal Of Multidisciplinary Empirical Research, VI, 1(1), 96-102.

Robinson, H. (2017)."Dualism", in Zalta, E., N.( Ed)The Stanford Encyclopedia of Philosophy (Fall 2017 Edition), Retrieved from https://plato.stanford.edu/archives/fall2017/entries/dualism/

Soyinka, W. (1963). The Lion and the Jewel. Ibadan: Oxford University Press.

Soyinka, W. (1974). Selected Plays. Oxford: Oxford University Press.

Bazimaziki, G. (2020). Duality in two west african literary genres: achebe's a man of the people and soyinka's the lion and the jewel. International Journal of Linguistics, Literature and Culture, 6(6), 1-7. https://doi.org/10.21744/ijllc.v6n6.961 